臨床セミナーI

\title{
実地医家における嗅覚障害診断手順
}

\author{
小林 正 佳 \\ 三重大学大学院医学系研究科耳鼻咽喉・頭頸部外科
}

はじめに

近年, 嗅覚, 味覚に対する社会的関心が高まり, 嗅覚 障害を訴えて耳鼻咽喉科を受診する患者が増加してい る。しかし現在, すべての耳鼻咽喉科診療施設において 嗅覚障害に対する診療体制が十分に整っているわけでは ない。とりわけ， T\& Tオルファクトメーターを用いた 基準嗅力検査を実施し, 嗅覚機能を客観的に評価した上 で嗅覚障害の診療を施行している施設が少ない。このた めか, 実際に嗅覚障害の原因, 病態の診断に苦慮する症 例は決して少なくない。この現状に対して，嗅覚障害診 療のガイドラインの確立が望まれるが, 現時点でそれは まだ完成していない。今回, 嗅覚障害の診療における診 断手順を紹介し, 上記の現状を踏まえた上で, 実地診療 の場で今後どのように嗅覚障害の診断を行うのがよいか を考察する。

\section{問 診}

嗅覚障害の診断を行う過程で, 最初の問診は重要であ る。適切に問診することで原因, 障害程度, 日常生活へ の影響など診療に必要な情報を得る。特に感冒, 軽微な 頭部外傷, 加齢, 薬物が原因である嗅覚障害例では, 後 述する鼻腔内所見, 画像所見上異常所見を認めないこと が多く，問診が診断の決め手となる。また嗅覚障害の病 態は単に嗅力の低下だけではなく，異常なにおいを自覚 する異嗅症もあり，これは問診でしか把握することがで きない。嗅覚の低下は香りがわからないことによる味覚 低下である風味障害を生じる原因にもなるので, 味覚障 害の合併の有無も確認する。嗅覚障害により食品の腐敗 臭, ガス漏れなどの感知力が低下すると, 健康を害する だけではなく時に生命を危険に晒すこともある。また食 品産業, 飲食店, 化粧品産業など, 職業上正常な嗅覚が 必要な人もいる。嗅覚障害がその患者にとってどの程度 生活の質 (QOL) に影響しているかも確認し, 嗅覚障 害に伴う生活上の注意点を指導する上での参考とする。

\section{耳鼻咽喉科的診察}

嗅覚障害の原因となり得る解剖学的部位は, 空中のに おい分子を受容する鼻部からにおい情報を認知する脳ま での経路にわたる。また原因となる疾患も鼻・副鼻腔炎 に代表される炎症性疾患や交通事故による頭部外傷, ア ルツハイマー病等の変性疾患など多種多様である。した がって，嗅覚障害の診断に必要な検査も多様なので，問 診で得られた情報に基づき, 症例に応じて適切に検査を 選択することが重要である。一般的な耳鼻咽喉科検査と して, 鼻・副鼻腔の診察には前鼻鏡検査, 軟性ファイバ ースコープ検査を行う。これらの検査で, におい受容体 の存在する嗅粘膜へにおい分子が到達するのを妨げる病 変がないかを確認する。さらに嗅粘膜が存在する嗅裂の 深部や嗅粘膜そのものの病変を確認するには, 細径ファ イバースコープや針状硬性鏡で観察する。使用に際し て, 嗅裂粘膜の所見変化や引き続き施行する嗅覚機能検 查の結果への影響を避けるため，通常は施行する局所表 面麻酔薬や血管収縮薬による前処置を行わずに観察する のが望ましい。ただし，患者に苦痛を与えないようにす るためには熟練が必要である。

\section{画像検査}

従来, 鼻部単純レントゲン撮影, 嗅裂部断層撮影が用 いられてきたが, 画像診断学が発達した現在は, 解像度 に優れ，診断が容易な CT が有用である。冠状断，骨条 件での撮影で, 副鼻腔炎, ポリープの有無, 鼻中隔や鼻 甲介の状況，嗅裂の開放の有無等の情報が容易に得られ る。嗅裂に明らかな異常所見がなくても篩骨洞の慢性炎 症が嗅覚障害の原因となる例もある。また CT 画像はそ のまま副鼻腔炎などの手術的治療の参考にもなる。造影 は通常不要であるが, 腫瘍性疾患を疑う場合には造影撮 影も施行する。MRI は頭蓋内病変, 嗅球や嗅覚中枢の 異常を疑う例に施行する。外傷性嗅覚障害, 脳腫瘍, Kallmann 症候群その他の先天性嗅覚障害, アルツハイ マー病などの神経変性疾患の診断に有用である。 


\section{嗅覚機能検査}

現在日本で医療保険の適用が認められている検査は $\mathrm{T} \& \mathrm{~T}$ オルファクトメーターを用いる基準嗅力検査とア リナミン注射液 ${ }^{\circledR}$ を用いる静脈性嗅覚検査の 2 種類のみ である。またこれらは日本の労災保険の障害認定のため の検査としても採用されている。

\section{1. 基準嗅力検査}

医療保険上の名目は基準嗅覚検査であるが，基本的に 域值検査であるため, 最近は基準嗅力検査と呼ぶのが推 奨されている。 5 種類の基準臭について，それぞれ薄い 濃度から10倍希釈で 8 段階（1 種類のみ 7 段階）を嗅が せて，最初に何らかのにおいを感じた濃度を検知域值， さらににおいの種類を同定できた濃度を認知域值とす る。 5 種類の検知域值, 認知域值の平均值をそれぞれ計 算して障害の程度を数值で表す。診断は平均認知域值に 基づいて，正常から嗅覚脱失までの 5 段階に障害程度を 分類する。

本検查法の長所は, 嗅力を具体的に数值化できるた め, 患者が検查結果を理解しやすく, 治療効果の判定に も使用できること，検知域值と認知域值の両方を測定で きることである。短所は検査時間が長く煩雑なこと，検 査時に嗅素が拡散するため室内のにおい污染が生じやす

く, 脱臭装置が必要なことである。

2. 静脈性嗅覚検査

アリナミンテストとも呼ばれる。アリナミン注射液 ${ }^{\circledR}$ （一般名プロスルチアミン， $10 \mathrm{mg} ， 2 \mathrm{ml}$ ) を肘正中静脈 へ20秒間等速度で注射し, 注入開始からニンニク臭（夕 マネギ臭）を感じるまでの時間（潜伏時間）と，におい を感じ始めてから消失するまでの時間（持続時間）を測 定する。嗅覚正常者の潜伏時間は $8 \sim 10$ 秒，持続時間は 60秒以上であり，嗅覚障害者では潜伏時間が延長し，持 続時間が短縮する。全くにおいを感知できなければ嗅覚 脱失である。潜伏時間は被検者の嗅覚域值の上昇に伴っ て延長し, 持続時間は嗅覚域值の上昇と嗅覚疲労の起こ りやすさの両方によって短縮すると考えられている。

この検査法の長所は, 簡便で短時間で施行でき, 鋭敏 に反応すること, 安価であること, 呼吸性嗅覚障害と他 の嗅覚障害の区別診断ができること，そして検査結果が 予後をよく反映することである。短所は，注射という身 体侵襲を伴い，まれに血管痛を生じること，嗅覚域值， 障害度の判定ができないことが挙げられる。

\section{3. 嗅覚同定検査}

におい感覚の鋭敏度を調べる域值検査に対して，にお い感覚の認知度を調べる検査である。現在日本で保険適
用されているものはない。欧米諸国では UPSIT(University of Pennsylvania Smell Identification Test), Sniffin' Sticks などが広く使用されているが，日本人になじみの ない嗅素，検査方式が採用されていることなどから，日 本では普及していない。これに代わって，日本人向けの スティック型嗅覚同定検査, その改良版であるカード型 嗅覚同定検査「オープンエッセンス」が開発されてい る。これらの検査は簡便性に優れ，嗅覚正常者，障害患 者の両者に対する有用性が産業技術総合研究所, 日本鼻 科学会嗅覚検查検討委員会とその関連施設から報告され ている。とくに同定検査であるにもかかわらず，検査結 果が基準嗅力検査の結果と強く相関する。スクリーニン グのみならず嗅覚障害の程度を判定する臨床検査として の活用が期待されている。

4. 日常のにおいアンケートとVisual analog scale (VAS)

嗅覚障害の自覚症状の評価法で, 日本鼻科学会嗅覚検 查検討委員会が作成した。日本人が日常生活で経験しや すいにおいの名前20項目を呈示して，それらのにおいが 分かるかをアンケート方式で回答してもらい，スコア化 する。この結果が嗅覚障害の自覚的低下度（5段階評価 法)，基準嗅力検査の結果とも有意に相関することが報 告されている。これはあくまでもアンケートではあるも のの, 嗅覚障害の程度, 嗅覚改善効果の判定に補助的に 使用可能である。

VAS 法は元々自覚的疼痛評価の指標として開発され たものであるが，現在は様々な臨床的自覚症状の評価に 活用されている。嗅覚障害の自覚的評価法としてもその 有用性が報告されている。

\section{嗅覚障害診断の問題点}

2006年に日本鼻科学会嗅覚検査検討委員会が施行した 全国調査によれば，医院（診療所）と一般病院における 基準嗅力検査の施行率は $10 \%$ 前後と低く，大学病院なと の医育施設でも $40 \%$ である。操作の煩雑性と室内のにお い拡散污染などが低施行率の理由と考えられる。現在の ところ, 実地医家における嗅覚障害の診断は主にファイ バースコープ，単純レントゲン撮影，静脈性嗅覚検査に よって施行され，障害程度と治療効果の判定は自覚症状 によりなされている。静脈性嗅覚検査は予後判定検査と して有用であるが，嗅覚障害の程度を判定する検査では ないので，現在の嗅覚障害の診断における最大の問題点 は，嗅覚障害の程度を評価する嗅覚検査を施行せずに嗅 覚障害の診断がなされていることである。スティック型 嗅覚同定検査とカード型嗅覚同定検査「オープンエッセ 
表 1 現状を踏まえた嗅覚障害の診断手順

\begin{tabular}{|c|c|c|}
\hline & 診療所 & 病院 \\
\hline 原因 · 病態診断 & $\begin{array}{l}\text { 問診 } \\
\text { ファイバースコープ検査 }\end{array}$ & $\begin{array}{l}\text { 問診 } \\
\text { ファイバースコープ検査 } \\
\text { CT } \\
\text { MRI }\end{array}$ \\
\hline 障害程度の診断 & $\begin{array}{l}\text { 日常のにおいアンケート } \\
\text { VAS } \\
\text { (スティック型嗅覚検査) } \\
\text { (カード型嗅覚検査) }\end{array}$ & $\begin{array}{l}\text { 日常のにおいアンケート } \\
\text { VAS } \\
\text { (スティック型嗅覚検査) } \\
\text { (カード型嗅覚検査) }\end{array}$ \\
\hline 予後診断 & 静脈性嗅覚検査 & 静脈性嗅覚検査 \\
\hline
\end{tabular}

ンス」は簡便性に優れ，臨床的有用も証明されているの で，今後の普及が期待されるが，まだ医療保険適用が認 められていないという問題がある。

\section{実地診療でどこまでするのか，できるのか}

このように本来常備されるべき基準嗅力検査が普及し ていない現状ではあるが，一方で，多くの嗅覚障害の原 因は副鼻腔炎と感冒であるため, 上述の問診, 鼻腔内診 察，単純レントゲン撮影により，実地医家において多く の嗅覚障害の診断は可能と考える。嗅覚検査の低普及に 対する次善の策として「日常のにおいアンケート」を活 用する。ただし，これはあくまでも問診に基づく補助手 段にすぎないので, 今後, 実地医療の現場で使いやすい 簡便な嗅覚同定検査の医療保険適用認可を求めていくの
が重要であると考える。

また，病診連携をうまく活用し，CT，MRI，基準嗅 力検査など，診療所で施行できない検査があれば，連携 病院に検査を依頼してカバーしてもらい，また原因不明 例など診療困難な嗅覚障害例に対しては，嗅覚専門外来 を設置している施設と連携して診療を進めるのがよいと 考えられる。

\section{ま と め}

以上のまとめを表 1 に示す。一見困難と考えられがち な嗅覚障害の診断も実地医家ができることは多くある。 できることを確実に行うことが重要であり，それが成さ れれば日本の嗅覚障害診療はさらに発展するであろうと 考える。 